\title{
INDUCING RESISTANCE IN COTTON PLANTS, GOSSYPIUM BARBADENSE L. AGAINST SOME INSECT PESTS BY PLANT GROWTH REGULATORS
}

\author{
MOHAMED, E. M. ${ }^{1}$, HANAN . F. ABDEL - HAFEZ ${ }^{2}$ \\ and MAHASEN A. ABDL- AZIZ ${ }^{1}$
}

1. Sids Agric. Res. Station, Plant Protection Res. Institute, ARC, Giza

2. Cotton Pesticides Bioassy Dept, Plant Protection Res. Institute , ARC, Giza

(Manuscript received 12 November 2009)

\begin{abstract}
Induced resistance in cotton plants Gossypium barbadense L. against some insect pests was studied by application of the plant growth regulators, Pix , Uniconazole and Amcoton in green house and field experiments during 2007 and 2008 seasons. The Pix and Uniconazole treatments reduced the entering of $1^{\text {st }}$ larval instars of spiny bollworm (SBW) and pink bollworm (PBW) to bolls, significantly. The percentage of larval penetration and development in bolls were $(35.0,36.37 \%)$ and $(48.7,53.89 \%)$ for SBW and PBW, respectively as a compared with control (56.57, $88.33 \%$ ) during 2007 season in green house experiment. The plant growth regulators, Pix and Uniconazole increased significantly some chemical constituents of cotton plants such as carotenoids and the total phenol content in both seasons.

In the field experiments, the plant growth regulators, Pix and Uniconazole caused earliness than control by $17.2,10.96 \%$ in the early planting date, and it was 12.59 and $10.37 \%$ in the late planting date. Pix and Uniconazole were the most effective treatments against cotton bollworms. The seasonal average bollworm infestation were $(10.77,11.47)$, and $(13.5,15.27)$ when applied in two planting dates, respectively, as compared with 16.07 and 19.33 in the control. The plant growth regulator, Amcoton produced the lowest and non significant effect against cotton bollworms. All treatments produced non significant effect against Jassids, Aphids and mature stage of white fly.
\end{abstract}

\section{INTRODUCTION}

Cotton is a crop of great economic importance in Egypt. This plant is susceptible to infestation by several insect pests. Low yield of cotton is mainly related to damage in bolls caused by the pink bollworm, P. gossypiella and the spiny bollworm, E. insulana which attacked the fruiting portions, squares, flowers and green bolls reducing both quantity and quality of the harvested lint and seeds during the late season. The main way for controlling these pests is still by using chemical insecticides. One of the most economically and ecologically suitable elements in pest management is host plant resistance. Mechanisms of resistance can be induced by cultural methods, soil fertilizers or plant growth regulators. Plant growth regulators are applied to control undesirable vegetative growth of crop plants, enhancing fruiting bodies and increasing yield. The 
application of Pix has proved in controlling the excessive vegetative growth and enhancing the fruiting bodies of cotton which subsequently increased the yield. (AbdelAl et al., 1986, Reddy et al., 1990 and 1992) and Abdel - Al (1998). However, Hodges et al., (1991) reported the increased photosynthetic rate in Pix treated cotton. The changes occurred due to the action of growth regulators in plant may affect the insect plant interactions. Zummo et al. (1984) studied the effects of the plant growth regulator, Pix (mepiquate chloride) on bollworm $H$. zea growth, survival and damage to cotton fruit in Texas. They indicated that application of Pix to cotton induced resistance to H. zea. Zhang et al. (1996) showed that application of plant growth regulator Pix during the flower and boll period at $30-45 \mathrm{gm} / \mathrm{ha}$. induced resistance in cotton plants against bollworms. Kassem and Namich (2003) reported that Pix spraying increased significantly chlorophyll ( $\mathrm{a}, \mathrm{b}$ and total), carotenoids and phenolic compounds in treated cotton plants. The present work aimed to study the induced resistance in cotton plants against some insect pests by plant growth regulators to evaluate the bioactivity of some plant growth regulators against infestation with some insect pests.

\section{MATERIALS AND METHODS}

\section{Induced resistance in cotton plants against cotton bollworms}

\subsection{Green house experiments}

Seeds of cotton Gossypium barbadense L. Var. Giza 80 were planted in 24 pots during the $1^{\text {st }}$ week of March inside green house. After establishment, seedlings were thinned to two plants / pot. Pots were watered weekly. No insecticides were applied to cotton plants. Each test was replicated 3 times in a randomized complete block design. These inducers were sprayed by hand sprayer on cotton plants, at two regimes with $1^{\text {st }}$ flower and two weeks after $1^{\text {st }}$ flower. Bolls formed 18-20 days after flowering were artificially infested with SBW and PBW (Laboratory reared). At least 2 - 4 green bolls / plant were infested with two $1^{\text {st }}$ instar PBW and SBW larvae (2 larvae / boll). Infested bolls were marked with colored polyethylene strips and were harvested 7days later. Samples were kept in tightly closed tissue bags and transferred to the laboratory for examination. The numbers of larvae that entered and developed in bolls were determined.

In order to estimate the chemical changes in cotton plants, samples of three mature fresh leaves were taken from the middle part of plant 3 replicates were carried out in the end of experiments to determine the chemical constituents such as chlorophyll $\mathrm{a}, \mathrm{b}$ and carotenoides. The photosynthetic pigments were extracted by pure acetone (85\%) according to the method of A.O.A.C. (1985). The optical densities of pigments (chlorophylls $\mathrm{a}, \mathrm{b}$ and carotenoids) were measured colorimetrically at the 
wave length 662, 644 and $440 \mathrm{~nm}$. respectively. The concentration of pigments were then expressed in $\mathrm{mg} / \mathrm{gm}$ fresh weight of leaves.

Total soluble phenols were colormetrically determined in fresh bolls using spectrophotometer at wave length $730 \mathrm{~nm}$ as described by A.O.A.C. (1985) and modified by Daniel and George (1972) using the standard curve of pyrogallol. The quantity of the total soluble phenols was determined as $\mathrm{mg} / \mathrm{gm}$ fresh weight.

\subsection{Field experiments}

Field studies were carried out to evaluate some inducers in cotton plants against cotton bollworm from March until September during the two successive seasons, 2007 and 2008.Cotton variety Giza 80 was sown on March, $5^{\text {th }}$ and $2^{\text {nd }}$ April, respectively. The experimental design was randomized blocks into four replicates. The whole cultivated area was divided into 32 plots. Every plot was $1 / 100$ fed.. The normal recommended agronomic practices were followed in all plots. The used inducers were the following plant growth regulators $\left(\mathrm{PGR}_{\mathrm{S}}\right)$ :

Pix: Mepiquat chloride (1,1-dimethyl piperidinium chloride) Produced by Basf company. The rate of application was $250 \mathrm{~cm}^{3} /$ fed.

Uniconazole : Company code name : S- 3307D ( E- 1 - ( p- chlorophenyl ) - 4, 4

- dimethyl- 2 - ( 1,2,4 - triazol-1- yl) - 1- penten-3-ol.) Produced by Sumitomo Chemical Co., The rate of application was $50 \mathrm{gm} / \mathrm{fed}$.

Amcoton : It consists of 1-Naphthyl acetic acid $0.45 \%$, 1- Naphthyl acetamid $1.20 \%$ and Inert ingredients $98.35 \%$. The rate of application was $60 \mathrm{gm} / \mathrm{fed}$.

These inducers were sprayed at the previously mentioned recommended rates twice every 15 days on cotton plants, at two regimes with $1^{\text {st }}$ flower and two weeks after $1^{\text {st }}$ flower. The percent infestation of cotton bollworms were determined starting from the mid of June until the end of August. Four replicates of each treatment. Each 25 cotton bolls were collected and examined weekly. The infestation of sap - sucking pests was recorded at weekly interval from randomly selected 5 plants per replicate. Samples of 5 plants were taken in every replicates to determine the following parameters: plant length in cm, number of fruit branches, green bolls and open bolls.

\section{RESULTS AND DISCUSSION}

\section{Green house experiments}

\section{Application of some plant growth regulators (PGR's)}

One of the most ecological and biotechnical methods of controlling insect pests in cotton plants is the induced host resistance.

To evaluate the effect of the different plant growth regulators ( PGR's) for controlling the cotton bollworms attacking cotton fruiting parts, an experiment was carried out in the green house at Sids region in Beni- Suef Governorate during the 2007 and 2008cotton growing seasons. 
Results in Table (1) shows the effect of some plant growth regulator, PGR,s on the artificially infested with SBW , PBW and some chemical constituents of Giza 80 cotton varity. The Pix and Uniconazole treatments reduced the entrance of 1st larval instar of SBW and PBW to bolls, significantly. The percentage of larval penetration and developed in bolls were $(35.0,36.67 \%)$ and $(48.7,53.89 \%)$ for SBW and PBW , respectively as a compared with control ( $56.67,88.33 \%$ ) during 2007 season. The Amcoton treatment was non significantly differed as compared to untreated check. In 2008 season, the percentage of larval penetration and development were (43.33, $50.0)$ and $(33.33,56.67 \%)$ for SBW and PBW as compared with control (73.33 and $76.67 \%)$, respectively.

The plant growth regulators, Pix and Uniconazole increased significantly some chemical constituents of cotton plants such as carotenoids $(0.88,0.76)$ and $(0.82$, 0.57) $\mathrm{mg} / \mathrm{g}$ fresh weight) in both season compared with untreated check $(0.73$, $0.67)$, respectively. The total phenol content $(14.67,13.40)$ and $(14.63,13.03) \mathrm{mg} /$ $\mathrm{g}$ fresh weight compared with untreated check $(11.53,11.80)$, respectively. None of the treatments Pix and Uniconazole as well had significant effects on chlorophyll $(a, b)$ content in both seasons.

Table 1. Effect of different inducers ( PGR,S ) on the artificially infested with SBW and PBW and some chemical constituents of Giza 80 cotton.

\begin{tabular}{|c|c|c|c|c|c|c|c|c|c|c|c|}
\hline \multirow{4}{*}{ 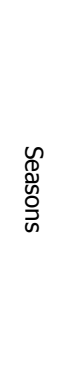 } & \multirow{4}{*}{ Treatments } & \multirow{2}{*}{\multicolumn{3}{|c|}{ E. insulana }} & \multirow{2}{*}{\multicolumn{3}{|c|}{ P. gossypiella }} & \multicolumn{4}{|c|}{$\begin{array}{l}\text { Some chemical constituents of } \\
\text { cotton plants }\end{array}$} \\
\hline & & & & & & & & & Chlo & ylls & \\
\hline & & \multicolumn{2}{|c|}{ No. of larvae } & \multirow{2}{*}{$\begin{array}{l}\text { Av. } \% \text { Larval } \\
\text { penetration }\end{array}$} & \multicolumn{2}{|c|}{ No. of larvae } & \multirow{2}{*}{$\begin{array}{c}\text { Av. \% } \\
\text { Larval } \\
\text { penetration }\end{array}$} & phenols & a & $b$ & 产 \\
\hline & & 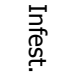 & $\begin{array}{l}\stackrel{0}{\mathbb{D}} \\
\stackrel{\mathbb{D}}{+}\end{array}$ & & 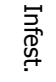 & $\begin{array}{l}\stackrel{D}{\mathbb{D}} \\
\stackrel{\mathbb{W}}{+}\end{array}$ & & \multicolumn{4}{|c|}{$\mathrm{mg} / \mathrm{gm}$ fresh weight } \\
\hline \multirow{4}{*}{2007} & Pix & 60 & 21 & $35.00 \mathrm{a}$ & 58 & 28 & $48.70 \mathrm{a}$ & 14.67 & $5.13 \mathrm{a}$ & 1.65 & $0.88 \mathrm{a}$ \\
\hline & Uniconazole & 60 & 22 & $36.67 \mathrm{a}$ & 58 & 31 & $53.89 a$ & 14.63 & $4.50 \mathrm{~b}$ & 1.70 & $0.82 \mathrm{~b}$ \\
\hline & Amcoton & 60 & 30 & $50.00 \mathrm{~b}$ & 60 & 47 & $78.33 \mathrm{~b}$ & 12.41 & $4.60 \mathrm{~b}$ & 1.60 & $0.75 \mathrm{c}$ \\
\hline & Control & 60 & 34 & $56.67 b$ & 58 & 48 & $83.33 b$ & 11.53 & $4.33 \mathrm{~b}$ & 1.63 & $0.73 \mathrm{c}$ \\
\hline \multicolumn{2}{|c|}{$F$ value } & --- & --- & 24.8 & --- & --- & 60.64 & 3.47 & 6.29 & 0.37 & 7.01 \\
\hline \multicolumn{2}{|c|}{ L.S.D at $5 \%$ level } & --- & --- & 7.24 & --- & --- & 7.66 & 2.8 & 0.49 & n.s & 0.09 \\
\hline \multirow{4}{*}{2008} & Pix & 30 & 13 & $43.33 \mathrm{a}$ & 30 & 10 & $33.33 \mathrm{a}$ & $13.40 \mathrm{a}$ & 4.87 & 1.45 & 0.76 \\
\hline & Uniconazole & 30 & 15 & $50.00 \mathrm{a}$ & 30 & 17 & $56.67 \mathrm{~b}$ & $13.03 b$ & 4.37 & 1.67 & 0.57 \\
\hline & Amcoton & 30 & 20 & $66.67 \mathrm{~b}$ & 30 & 22 & $73.33 \mathrm{c}$ & $11.60 \mathrm{c}$ & 4.93 & 1.58 & 0.68 \\
\hline & Control & 30 & 22 & $73.33 \mathrm{~b}$ & 30 & 23 & $76.67 \mathrm{c}$ & $11.80 \mathrm{c}$ & 4.40 & 1.47 & 0.67 \\
\hline \multicolumn{2}{|c|}{ F value } & --- & --- & 10.6 & --- & --- & 8.65 & 3.9 & 1.03 & 3.39 & 0.89 \\
\hline \multicolumn{2}{|c|}{ L.S.D at $5 \%$ level } & --- & --- & 14.84 & --- & --- & 23.2 & 1.56 & n.s & n.s & n.s \\
\hline
\end{tabular}


* The values marked with the same letter are not significantly different according to the value to the L. S. D. test at $5 \%$ level.

These results agree with those outlined by Zummo et al. (1984) who showed that after Pix treatment a relatively condensed tannin concentration and astringency increased significantly in treated plants. Heliothis larvae developing on these plants weighed less, had lower survival rates and damaged less fruit than larvae on untreated plants. They indicated that application of Pix to cotton induced plant resistance to $H$. zea infestation. Also, Mansour et al. (1997) found a negative linear relationship between the concentration of tannins in two Egyptian varieties, Giza 70 and Giza 76 and the population density of piercing sucking insects. Zhang et al. (1996) mentioned that earliness, Okra leaf, lack of nectarines, smooth leaf and high gossypol content were found to be correlated with resistance to Pectinophora. gossypiella, while dense leaf pubescence and low gossypol were correlated with susceptibility to the pest.

\section{Field experiments}

\subsection{Effect of different plant growth regulators on vegetative and fruiting characters}

It is obvious from the results presented in Table 2, which show the effect of different inducers on the average of some growth characters i.e. plant height, fruiting branches, bolls and open bolls in two sowing dates. The plant growth regulators Pix and Uniconazole decreased the average plant height significantly. The average plant heights were $(123.9,129.8)$ in the early panting date and $(124.8,128.5) \mathrm{cm} /$ plant in the late planting date, respectively as compared with control ( 135.9 and $140.7 \mathrm{~cm}$ ( plant ), while the plant growth regulator Amcoton produced non significant height differences compared with the untreated plots in both planting dates.

The plant growth regulators, Pix and Uniconazole significantly increased the average number of fruiting branches. The average number of fruiting branches were $(18.9,17.6)$ and $(19.7,16.1)$ branch / plant, respectively as compared with control (16.7, 12.3 branch / plant) in both planting dates, respectively. The plant growth regulator Amcoton did not produce a significant different number of fruiting branches.

The plant growth regulators, Pix and Uniconazole increased the average number of green bolls and open bolls / plant significantly. The average number of green bolls and open bolls were ( $40.3,31.3)$ and $(39.0,27.7)$, respectively , as compared with $(32.3,17.1)$ in untreated plants in the first planting date (5 March). They were (31.9, 21.7 ) and $(29.3,18.1)$, respectively, in the second planting date. The plant growth regulator Amcoton did not significantly increase the average number of green bolls and open bolls. 
Table 2. Effect of different inducers ( $P G R, S$ ) on the average of some plant growth characters and percentage of earliness in bolls opening of Giza 80 cotton sowing in two dates.

\begin{tabular}{|c|c|c|c|c|c|c|c|c|}
\hline \multirow[b]{3}{*}{$\begin{array}{l}\text { Planting } \\
\text { dates }\end{array}$} & \multirow[b]{3}{*}{ Treatments } & \multicolumn{7}{|c|}{ Vegetative and fruiting characters } \\
\hline & & \multirow[b]{2}{*}{$\begin{array}{l}\text { Plant } \\
\text { height } \\
(\mathrm{cm})\end{array}$} & \multicolumn{4}{|c|}{ Av. No. / plant } & \multicolumn{2}{|c|}{ Boll opening } \\
\hline & & & $\begin{array}{l}\text { Fruiting } \\
\text { branches }\end{array}$ & bolls & $\begin{array}{l}\text { Open } \\
\text { bolls }\end{array}$ & $\begin{array}{c}\% \\
\text { opened } \\
\text { bolls }\end{array}$ & $\begin{array}{l}\text { Period } \\
\text { to } 1^{\text {st }} \\
\text { boll in } \\
\text { days }\end{array}$ & $\begin{array}{c}\% \\
\text { earliness }\end{array}$ \\
\hline \multirow{4}{*}{ 5- March } & Pix & $123.9 \mathrm{a}$ & $18.9 \mathrm{a}$ & $40.3 a$ & $31.3 a$ & 77.58 & 121 & 17.12 \\
\hline & Uniconazole & $129.8 b$ & $19.7 \mathrm{a}$ & $39.0 \mathrm{a}$ & $27.7 a$ & 71.05 & 130 & 10.96 \\
\hline & Amcoton & $133.9 \mathrm{~b}$ & $17.4 \mathrm{~b}$ & $35.0 \mathrm{~b}$ & $20.8 \mathrm{~b}$ & 59.33 & 142 & 2.74 \\
\hline & Control & $135.9 b$ & $16.7 \mathrm{~b}$ & $32.3 \mathrm{~b}$ & $17.1 \mathrm{~b}$ & 52.99 & 146 & 0.00 \\
\hline \multicolumn{2}{|c|}{ F value } & 8.77 & 8.55 & 5.9 & 19.04 & --- & --- & --- \\
\hline \multicolumn{2}{|c|}{ L.S.D at $5 \%$ level } & 6.19 & 1.59 & 5.19 & 5.04 & --- & --- & --- \\
\hline \multirow{4}{*}{2 - April } & Pix & $124.8 \mathrm{a}$ & $17.6 \mathrm{a}$ & $31.9 a$ & $21.7 a$ & 67.95 & 118 & 12.59 \\
\hline & Uniconazole & $128.5 \mathrm{a}$ & $16.1 \mathrm{~b}$ & $29.3 a$ & $18.1 \mathrm{a}$ & 61.96 & 121 & 10.37 \\
\hline & Amcoton & $138.2 \mathrm{~b}$ & $13.9 \mathrm{~b}$ & $24.3 \mathrm{~b}$ & $12.0 \mathrm{~b}$ & 49.59 & 133 & 1.48 \\
\hline & Control & $140.7 \mathrm{~b}$ & $12.3 \mathrm{~b}$ & $20.5 \mathrm{~b}$ & $10.0 \mathrm{~b}$ & 48.70 & 135 & 0.00 \\
\hline \multicolumn{2}{|c|}{ F value } & 12.99 & 44.47 & 14.15 & 21.26 & --- & --- & --- \\
\hline \multicolumn{2}{|c|}{ L.S.D at $5 \%$ level } & 5.67 & 4.21 & 4.7 & 4.03 & --- & --- & --- \\
\hline
\end{tabular}

* The values marked with the same letter are not significantly different according to the value to the L. S. D. test at $5 \%$ level.

In both planting dates, a time required for opening the first boll, in different treatments were also shortened than that of the control. The plant growth regulators, Pix and Uniconazole caused earliness than control by $17.2,10.96 \%$ ) in the early planting date and by 12.59 and $10.37 \%$ in the late planting date. The results agree with the finding of Kassem and Namich (2003) reported that Pix spraying significantly increased carotenoids and phenolic compounds in treated cotton plants and also increased chlorophyll ( $\mathrm{a}, \mathrm{b}$ and total ). Nobreqa et al. (1999) found that the application of pix ( mepiquate chloride) has enhancing effects on fruiting bodies of cotton which increased yield.Thakar et al., (1999) tested different growth regulators on cotton and found thiadiazuran increased harvestable bolls per plant, boll opening percentage, yield and decreased days to maturity. 


\subsection{Effect of some plant growth regulators (PGR's) on some insect pests of cotton}

To evaluate the effect of the plant growth regulators Pix , Uniconazole and Amcoton, on the cotton bollworms attacking cotton fruiting parts and some sap sucking pests, an experiment was carried out at Sids region in Beni-Suef Governorate during the 2006 and 2007 cotton growing seasons.

The data in Table 3 shows the effects of different inducers applied at different planting dates on the average bollworm infestation cotton plants with the PBW and SBW. The plant growth regulators pix, Uniconazole, and Amcoton were the most effective treatments against cotton bollworms. The seasonal average rates of bollworm infestation were $(10.77,11.47)$, and $(13.5,15.27)$ when applied in two planting dates, respectively as compared with 16.07 and 19.33 in the control. The plant growth regulator, Amcoton, produced the lowest effect against cotton bollworms and not significant with control.

Population fluctuation of Jassid and aphids after application of these inducers in cotton were evaluated, the results indicated that there was no significant effect of plant growth regulator on the population of Jassid and aphids in the two planting dates.

The effect of the plant growth regulators on the population of B. tabaci (immature and mature stages) varied significantly between the treatments Table (3). The most effective treatments against B. tabaci (immature and mature stages) were Pix and Uniconazole treatments. The seasonal average immature and mature stages / leaf were $(2.7,1.87)$ and $(3.07,1.9)$ in the first planting date, respectively, as compared with 3.87 and 2.27 in the control.These treatments gave good protection and it can be used as good agrochemical elements in cotton pest management strategies. 
Table 3. Effect of different inducers (plant growth regulators) on insect pest infestation in cotton sowing in two dates in the field.

\begin{tabular}{|c|c|c|c|c|c|c|}
\hline \multirow{3}{*}{$\begin{array}{l}\text { Sowing } \\
\text { dates }\end{array}$} & \multirow{3}{*}{ Treatments } & \multirow{3}{*}{$\begin{array}{l}\text { Av. bollworm } \\
\text { infestation \% }\end{array}$} & \multicolumn{4}{|c|}{ Seasonal $X \pm S . D$. pest population / cotton leaf) } \\
\hline & & & \multirow{2}{*}{ Jassid } & \multicolumn{2}{|c|}{ Whitefly } & \multirow{2}{*}{ Aphis } \\
\hline & & & & immature & mature & \\
\hline \multirow{4}{*}{ 5- March } & Pix & $10.77 \pm 5.58 a$ & $4.20 \pm 1.49$ & $2.70 \pm 0.17 a$ & $1.87 \pm 0.32 \mathrm{a}$ & $9.93+1.00$ \\
\hline & Uniconazole & $11.47 \pm 6.53 a$ & $4.47 \pm 1.54$ & $3.07 \pm 0.51 b$ & $1.90 \pm 0.26 a$ & $11.03+2.49$ \\
\hline & Amcoton & $14.37 \pm 6.50 b$ & $5.13 \pm 1.88$ & $4.27 \pm 0.58 c$ & $2.13 \pm 0.46 b$ & $11.30+2.86$ \\
\hline & Control & $16.07 \pm 8.09 b$ & $4.57 \pm 1.62$ & $3.87 \pm 0.55 c$ & $2.27 \pm 0.15 b$ & $11.23+1.82$ \\
\hline \multicolumn{2}{|c|}{ F value } & 5.11 & 1.17 & 8.59 & 5.56 & 3.13 \\
\hline \multirow{2}{*}{\multicolumn{2}{|c|}{$\begin{array}{c}\text { L.S.D at } 5 \% \text { level } \\
1 \%\end{array}$}} & 3.8 & r & 0.85 & 0.27 & \\
\hline & & 5.7 & 11.3 & 1.28 & 0.42 & 11.3 \\
\hline \multirow{4}{*}{ 2-April } & Pix & $13.50 \pm 8.86 a$ & $3.63 \pm 1.29$ & $3.90 \pm 0.66 a$ & $4.28 \pm 0.19$ & $11.87 \pm 1.35$ \\
\hline & Uniconazole & $15.27 \pm 9.81 \mathrm{a}$ & $3.33 \pm 1.21$ & $5.20 \pm 0.10 b$ & $5.07 \pm 0.10$ & $13.00 \pm 0.64$ \\
\hline & Amcoton & $18.87 \pm 8.91 b$ & $3.60 \pm 1.22$ & $6.57 \pm 0.35 b$ & $5.10 \pm 0.98$ & $13.60 \pm 1.00$ \\
\hline & Control & $19.33 \pm 9.35 b$ & $3.57 \pm 1.24$ & $6.03 \pm 0.74 b$ & $5.23 \pm 0.67$ & $12.87 \pm 0.95$ \\
\hline \multicolumn{2}{|c|}{ F value } & 9.38 & 0.26 & 14.52 & 1.95 & 0.29 \\
\hline \multirow{2}{*}{\multicolumn{2}{|c|}{$\begin{array}{l}\text { L.S.D at } 5 \% \text { level } \\
1 \%\end{array}$}} & 3.2 & \multirow{2}{*}{ n.s } & 1.04 & \multirow{2}{*}{ n.s } & \multirow{2}{*}{ n.s } \\
\hline & & 4.8 & & 1.57 & & \\
\hline
\end{tabular}

- The values marked with the same letter are not significantly different according to the value to the L. S. D. test at $5 \%$ level.

These findings are in agreement with other investigations carried out by several authors.Wilson et al. (1992) showed that the growth regulating chemical ethephone (2chloroethylphosphonic acid ) caused bolls to open earlier and decreased the number larvae of P. gossypiella over wintering. Abdel - Al et al. , (1986) and Abdel- Al ( 1998) showed that application of Pix to cotton cause bolls to open earlier and enhance crop maturity, increased the cotton yield / plant and induced resistance in cotton plants against bollworms than untreated check. This plant resistance may be due to that pix treatment inhibits the synthesis of the plant hormone gibberilic acid that plays a major role in enhancing cell enlargement and general vegetative growth. Ashfaq et al., (2001) , Ahmed et al (2003) and Abro et al. (2004) also, observed similar trend in the reduction of sucking pest and bollworm infestation treated with different doses of Pix. 


\section{REFERENCES}

1. Abdel - Al , M. H. 1998. Response of Giza 85 cotton cultivar to the plant growth regulator Pix and Atonik. Egypt. J. Agric. Res., 76 (3): 1173- 1181.

2. Abdel- Al , M. H. , E. T. Eid, M. S. Ismail and M. H. El- Akkad. 1986. Response of Egyptian cotton plants to Mepiquate chloride with varying concentrations and time of application. Annals of Agric. Sci. , Ain shams Univ., Cairo , 31 (2): 10771088.

3. Abro, G. H. , T. S. Syed , M. A. Unar and M. S. Zhang. 2004. Effect application of plant growth regulator and micronutrients on insect pest infestation and yield components of cotton, J. of Entomology, 1 (1): 12-16.

4. Ahmed, N. S. M., S. R. Masoon and A. R. Akbar. 2003. Efficiency of plant growth regulators to Manage the insect pests of cotton.. Asian J. of plant Sci. 2 (7): 544547.

5. A. O. A. C. (Association of Official Agriculture Chemists. 1985. Official Methods of Analysis $14^{\text {th }}$ Ed., Published by Washington, DC., U. S. A.

6. Ashfaq, M. , M. Y. Munir and A. Ali. 2001. Effect of pix, a plant growth regulator, on the development of major insect pests, growth and yield of cotton varity NIAB86. Balochistan J. Agric. Sci. , 2: 35-37.

7. Daniel , H. D. and C. M. George. 1972. Peach seed dormancy in relation to endogenous inhibitors and applied growth substances. J. Amer. Soc. Hort. Sci., 97 : 651-654.

8. Hodges, H.F., V.R. Reddy and K.R. Reddy. 1991. Mepiquat chloride Mepiquat chloride and temperature effects on photosynthesis and respiration of fruiting cotton. Crop Sci., 31: 1302-1308.

9. Kassem, M. M. A. and A. M. Namich. 2003. Response of Giza 83 cotton cultivar to sequential applications of gibberellic acid $\left(\mathrm{GA}_{3}\right)$ and mepiquat chloride ( Pix). J. Agric. Sci. Mansoura Univ., 28 (3) : 1611-1620.

10. Mansour, M. H. , N. M. Zohdy, S. E. El- Gengaihi and A. E. Amr 1997. The relationship between tannins concentration in some cotton varietiesand susceptibility to piercing sucking insects. J. Appl. Ent., 121, 321- 325.

11. Nobreqa, L. B., D. J. Vieva, N. E. Bellrao, D. M. P. Azeredo and D. M. D. Azenedo. 1999. Effect of growth regulator mepiquat chloride on cotton yield in the seraoi region of paraiba State, Brazil. RevistadeOleaginos as Fibrosas, 3: 89 - 92.

12. Reddy, V.R., D.N. Baker and H.F. Hodges. 1990. Temperature and Mepiquat chloride effects on cotton canopy architecture. Agron. J., 82: 190-195.

13. Reddy,V.R., A. Trint and B. Acock. 1992. Mepiquat chloride and irrigation versus cotton growth and development. Agron. J., 84: 930-933. 
14. Thakar, S. , Z. S. Brar and T. Singh. 1999. Effect of growth regulator and defoliant on yield and maturity of upland cotton Gossypium hirsutumL., under irrigated conditions. Indian, J. Agron.,44:179-184.

15. Wilson, F.D., H. M. Flint, W. R. Deaton, D. A. Fischhoff, F. J. Perlak, T. A. Armstrong , R. L. Fuchs, S. A. Berberich , N. J. Parks and B. R. Stapp. 1992. Resistance of cotton lines containing a Bacillus thuringiensis toxin to pink bollworm (Lepidoptera: Gelechiidae) and other insects. J. Econ. Entomol. 85: (4): 15161521.

16. Zhang, J. F., J. Z. Sun, Z. B. Wu and J. L. Lu. 1996. Mechanisms of pink bollworm resistance in upland cotton. Acta Agronomica Sinica. $19 \quad$ (5 ): 385394.

17. Zummo, G. R. , J. C. Segers and J. H. Bendict. 1984. Seasonal phenology of allelochemicals in cotton resistance to bollworm ( Lepidoptera, Noctuidae ). Environ. Entomol., 13(5): 1287- 1290. 


\section{تحفيز مقاومة نباتات القطن ضد بعض آفات القطن الحشرية باستخدام \\ منظمات النمو التباتية}

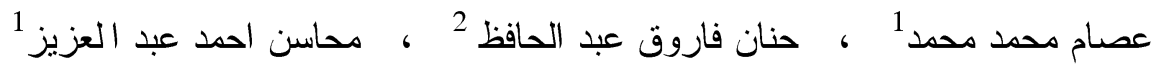

$$
\begin{aligned}
& \text { ا ـ محطة بحوث سدس - معهُ بحوث وقابة النباتات - مركز البحوث الزراعية }
\end{aligned}
$$

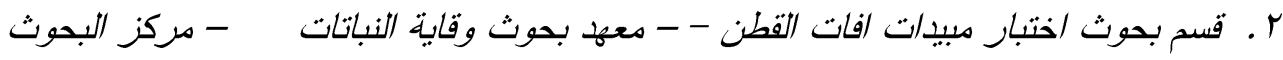

$$
\begin{aligned}
& \text { الزراعية }
\end{aligned}
$$

تم دراسة تحفيز مقاومة نباتات القطن Gossypium barbadense L. ضد بعض الآفات

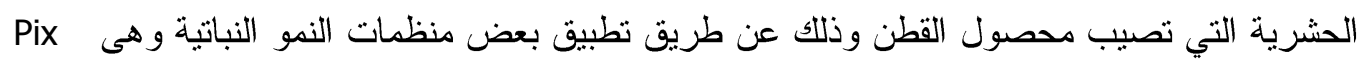

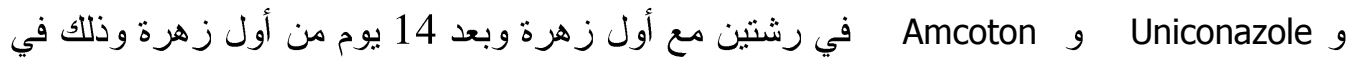

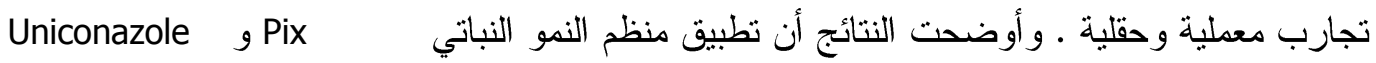
أحدث تحفيز النباتات القطن حيث خفض معنويا نسبة دخول وتطور العمر الأول من برقات دودة اللوز القرنفلية و الثوكية بعد العدوى الصناعية في تجارب الصوب خلا ل موسمي الدراسة 2007 و 2008

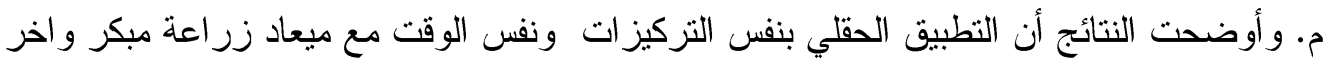

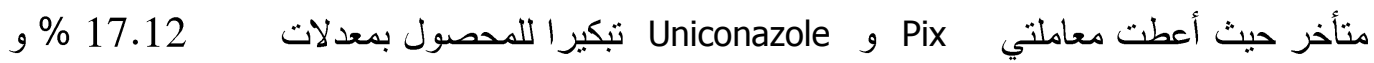
10.96 \% بالنسبة لميعاد الزراعة الأول و 12.59 \% و 10.37 \% بالنسبة لميعاد الزر اعة الثاني

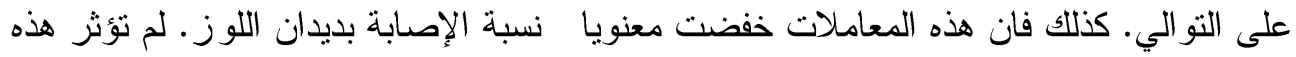

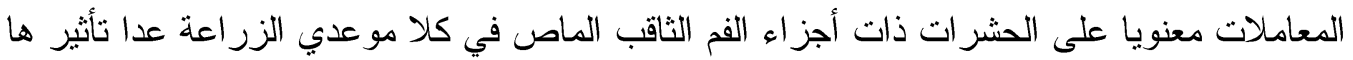

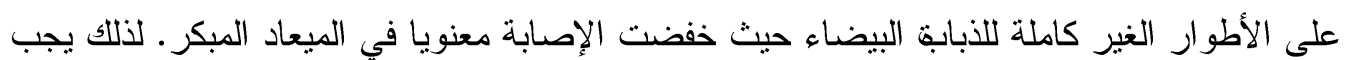

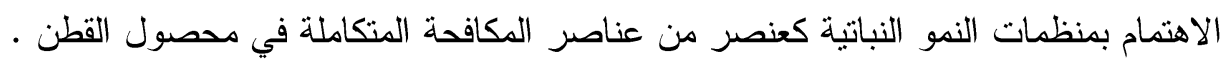

